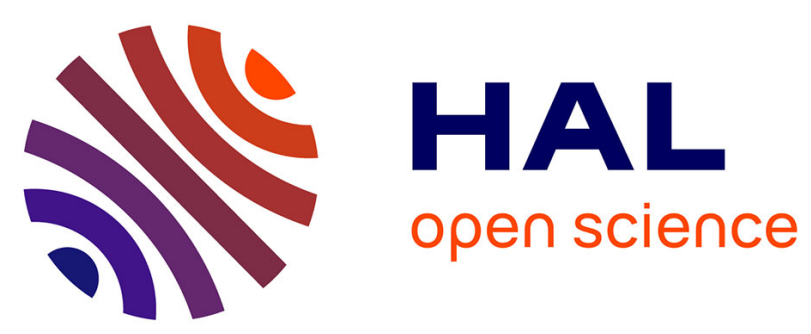

\title{
Clostridium difficile associated reactive arthritis: Case report and literature review
}

Paul Legendre, Valérie Lalande, Catherine Eckert, Fréderic Barbut, Laurence Fardet, Jean-Luc Meynard, Laure Surgers

\section{- To cite this version:}

Paul Legendre, Valérie Lalande, Catherine Eckert, Fréderic Barbut, Laurence Fardet, et al.. Clostridium difficile associated reactive arthritis: Case report and literature review. Anaerobe, 2016, 38, pp.76-80. 10.1016/j.anaerobe.2015.12.011 . hal-01252013

\section{HAL Id: hal-01252013 \\ https://hal.sorbonne-universite.fr/hal-01252013}

Submitted on 7 Jan 2016

HAL is a multi-disciplinary open access archive for the deposit and dissemination of scientific research documents, whether they are published or not. The documents may come from teaching and research institutions in France or abroad, or from public or private research centers.
L'archive ouverte pluridisciplinaire HAL, est destinée au dépôt et à la diffusion de documents scientifiques de niveau recherche, publiés ou non, émanant des établissements d'enseignement et de recherche français ou étrangers, des laboratoires publics ou privés. 
1 Clostridium difficile associated reactive arthritis: case report and

2 literature review

3

4 Paul Legendre ${ }^{1}$, Valérie Lalande ${ }^{2}$, Catherine Eckert $^{3}$, Fréderic Barbut ${ }^{2,3}$, Laurence Fardet ${ }^{4}$, Jean-Luc Meynard ${ }^{1}$, 5 Laure Surgers ${ }^{1,5}$

6

7 1. Service des Maladies Infectieuses et Tropicales, APHP, Hôpital Saint-Antoine, Paris, France

8 2. Laboratoire de Microbiologie, APHP, Hôpital Saint-Antoine, Paris, France

9 3. Laboratoire Clostridium difficile associé au Centre National de Référence des Bactéries Anaérobies, APHP, 10 Hôpital Saint-Antoine, Paris, France

11 4. Service de Médecine Interne, APHP, Hôpital Saint-Antoine, Paris, France

12 5. Sorbonne University, UPMC University Paris 06 CR7, Paris, France; INSERM U1135, CIMI, Team E13

13 Corresponding author

14 Dr Laure Surgers (laure.surgers@aphp.fr)

15 Service des Maladies Infectieuses et Tropicales

16 Hôpital Saint-Antoine, 184 rue du Faubourg Saint-Antoine

17 75012, Paris, France

18 Phone: +33171970119

19 Fax: + 33149282149 


\section{ABSTRACT}

Introduction: Extra-gastro-intestinal tract manifestations associated with Clostridium difficile infection (CDI), including reactive arthritis (ReA), are uncommon.

Method: We report a case of ReA associated with a relapse of $C D I$ in a 46 -year-old woman. $A$ toxigenic $C$. difficile strain was isolated from stools and characterized as PCR-ribotype 014/020/077. We conducted a comprehensive literature review of ReA associated with CDI (ReA-CDI). Diagnostic criteria for ReA-CDI were: (i) evidence of aseptic synovitis (confirmed by culture) developing during or immediately after colitis, (ii) presence of a toxigenic $C$. difficile strain in stool samples, and (iii) absence of other causes of colitis and arthritis.

Results: Forty-nine cases of ReA-CDI (excluding the present report) have already been described since 1976. Of these reports, Mean age of patients was 38 years (SD: 18.5 ), $46 \%$ were male, and $68 \%$ had HLA B27 genotype. Sixty-nine percent of patients received a $\beta$-lactamin treatment before CDI. ReACDI occurred a median 10 days (range 0-55 days) after CDI. Outcome was favorable in $90 \%$ of patients and oral non anti-inflammatory drugs were required for $55 \%$.

Conclusion: ReA-CDI remains uncommon. Compared to the general population, it is more likely observed in younger patients with HLA B27-positive genotype.

(1)

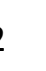

3

(1)

45

6




\section{INTRODUCTION}

Clostridium difficile (CD) is a strict anaerobic, spore-forming, gram positive bacillus. Only toxigenic strains of $C D$ are involved in gastro-intestinal tract infections. Clinical symptoms associated with $C D$ infections (CDI) generally range from mild diarrhea to severe pseudomembranous colitis (PMC). CDI is defined by several signs and symptoms, presence of $C D$ toxin and/or toxin-producing $C D$ in stools, and no other causes of PMC after colonoscopic or histopathological evaluation [1]. The incidence of $\mathrm{CDI}$ is increasing in many countries worldwide and $C D$ has a considerable burden on healthcare systems [2]. In particular, the United States Center for Disease Control and Prevention (CDC) recently placed CDI among bacterial infections posing the highest health risk due to antimicrobial resistance [3].

In Europe, the incidence of healthcare-associated CDI is 4.2 per 10,000 patient-days, with a casefatality rate of $9 \%$ within three months after diagnosis [4]. In the United States, there was a total of 453,000 estimated number of CDIs in 2011 based on data from active population- and laboratorybased surveillance [2]. Antibiotic use, advanced age, and comorbidities (liver cirrhosis, heart disease, pulmonary disease, chronic dialysis, immunocompromised status) are the most common risk factors associated with CDI [4].

Extra-colonic CDI have been described in previous reports and include bacteremia [5], cellulitis [4], pancreatic [6] or splenic abscesses [7], pleural empyema [8], osteomyelitis [5], native or artificial joint $[9,10]$, or appendicitis [10]. Extra-colonic manifestations have also been observed, such as uremic and hemolytic syndrome $[11,12]$ and reactive arthritis $(\operatorname{ReA})$, yet are probably unrelated to bacteria itself.

Birnbaum et al. proposed diagnostic criteria for ReA associated with CDI (ReA-CDI) [13], which include the following: i) evidence of aseptic synovitis (confirmed by culture) developing during or immediately after colitis, (ii) presence of toxins produced by $C$. difficile in stool samples, and (iii) absence of other causes of colitis and arthritis. The pathophysiology of Rea-CDI is poorly understood, while the underlying cause of its occurrence remains unknown.

We report herein a case of ReA-CDI observed in a 46-year-old woman and present a comprehensive review of previous cases in the literature.

\section{CASE REPORT}


A 46-year-old Caucasian woman was admitted to Saint-Antoine Hospital (Paris, France), for an acute episode of antibiotic-associated diarrhea.

She experienced iterative lower urinary tract infections (UTI) and chronic anemia due to iron deficiency. She reported no particular medication intake, no smoking, and no drug or alcohol use. She had no family history of or symptoms related to autoimmune disease.

Seven months before hospitalization, she had foot surgery as a result of hallux valgus. She reported large quantities of aqueous diarrhea that resolved after 10-day treatment with oral metronidazole. Stool testing was not performed at that time. Three weeks later, she developed oligoarthritis (both ankles and left knee), which lasted roughly 5 months and resolved during treatment with ketoprofene.

A few days prior to hospitalization, she was treated for a lower UTI with a two-day course of cefixim. She was admitted to the emergency room for severe diarrhea, vomiting and abdominal pain. Clinical examination revealed arterial pressure at $82 / 54 \mathrm{mmHg}$ (which was comparable to previous measures), tachycardia (110 bpm) and no other abnormalities. CD was detected in stool samples by enzyme immunoassay (GDH, Cdiff Quik $\mathrm{Chek}^{\circledR}$, Alere) and confirmed by polymerase chain reaction (PCR) toxin B detection (GenXpert ${ }^{\circledR}$, Cepheid) but not with a cell culture cytotoxicity assay. She underwent rehydration therapy and initiated a 10-day course of oral metronidazole. She had rapid clinical improvement and was discharged 2 days later.

She was readmitted 11 days after discharge for oligoarthritis (both ankles and left knee), fever (38. $1^{\circ} \mathrm{C}$ ), myalgia, and recurrence of diarrhea. Upon examination, both of her ankles and left knee were slightly swollen and painful. Stool samples tested positive for toxinogenic CD again, while this time the cell culture cytotoxicity assay was positive. Strains from both the first and second episodes were genotyped as PCR-ribotype 014/020/077.

Joint X-ray was normal. Blood and urine culture were sterile. Complete blood count was normal except for lymphocyte count at 1326 cells $/ \mathrm{mm}^{3}$, hemoglobin at $11.3 \mathrm{~g} / \mathrm{dL}$, and platelet count at $483,000 / \mathrm{mm}^{3}$. There were no other ion (including calcium) or renal abnormalities. C-reactive protein level was $114.6 \mathrm{mg} / \mathrm{L}$, plasmatic protein electrophoresis demonstrated pro-inflammation (increase in $\alpha-1, \alpha-2$ and $\gamma$-globulins). An intra-articular puncture of the knee was performed and showed high degrees of inflammation with 10,000 elements $/ \mathrm{mm}^{3}$, including $7300 / \mathrm{mm}^{3}$ polymorphic neutrophils, while no crystals were identified. Articular fluid was placed in bacteriological cultures, including incubation in anaerobic blood culture, which were negative. 
Oral vancomycin $125 \mathrm{mg}$ was given four times daily for 10 days to treat CDI. Afterwards, paracetamol and tramadol were administered to treat probable ReA-CDI. Arthritis and diarrhea fully resolved within 3 weeks. At the one-year follow-up visit, no recurrence of diarrhea or arthritis was reported.

\section{REVIEW}

We performed a review of all ReA-CDI cases published in the literature. We searched for the combined terms "Reactive arthritis" and "Clostridium difficile" in PubMed and obtained 41 articles amounting to 51 cases of ReA-CDI. We excluded 2 patients who did not have toxin detected in stool samples, per definition of CDI [15]. In total, we summarize 39 articles including 49 cases of ReA-CDI, all of which were reported among adults and children since 1976 [14,16-49] (Table 1).

Patients had a mean age of 38 years (SD: 18.5$)$ and were mostly females (54\%). Patients were noticeably younger than those included in a European survey of 2011 but the proportion of females was similar (56\%) [4]. HLA B27 genotype was observed in 28/41 patients $(68 \%, 95 \% \mathrm{Cl}: 53.7 \%-82.3$ $\%)$.

First-line treatment of CDI was metronidazole in 13/24 (54.2\%, 95\% Cl: $27.1-81.3 \%)$ and oral vancomycin in $11 / 24$ cases $(45.8 \%, 95 \% \mathrm{Cl}: 16.4-75.2 \%)$.

ReA occurred a median 10 days after CDI (range: 0-55 days). Of all 50 cases, initial presentation was monoarthritis in $9(18 \%, 95 \% \mathrm{Cl}: 7.4-28.6 \%)$, oligoarthritis in 22 (44\%, 95\% Cl: 30.2-57.8), and polyarthritis in 19 (38\%, 95\% Cl: $24.5-51.5 \%)$. The two joints most frequently involved in ReA-CDI were ankles (63.6\%, 95\% Cl: 45.8-81.4\%) and knees (59.1\%, 95\%Cl: 40.2-78\%). ReA-CDI lasted from 5800 days (median=42 days). Clinical outcome was favorable in 38/42 cases $(90.5 \%, 95 \% \mathrm{Cl}: 81.6-99.4$ $\%)$ as non steroid anti-inflammatory drugs were needed in $11 / 20$ cases $(55 \%, 95 \% \mathrm{Cl}$ : $33.2-76.8 \%)$. No reoccurrence of $\mathrm{CDI}$ was described in the literature.

None of the 49 cases presented in this review reported the specific ribotype strain involved in CDI. The patient in our case report was infected with CD PCR-ribotype 014/020/077, one of the most frequent strains in France and Europe [50,51]. Further studies exploring a possible association between ReA and CD strain would be helpful in this context.

There are few data regarding the pathological mechanism involved in ReA-CDI. It could be hypothesized that immunologic tolerance is interrupted during antigenic presentation and contributes to ReA-CDI. Indeed, a major bacterial structure, lipopolysaccharide (LPS), is commonly found in the blood of patients with ReAs before the onset of arthritis, owing to other entero-invasive 

pathogens such as Salmonella sp or Chlamydia trachomatis [52]. As CD is devoid of LPS, it remains to be demonstrated if other sources of circulating LPS or CD-antigen are present before the onset of ReA-CDI. CD-toxin A is known to increase permeability of the epithelial intestinal barrier [28]. As a result, CD-antigen and/or LPS from other gram-negative bacteria could reach blood circulation via the gut, driving an antigenic reaction and disrupting immunologic tolerance. Activated autoreactive T lymphocytes could then reach cartilage tissue and cause synovitis. Moreover, LPS from Escherichia coli is able to enhance the cytotoxicity activity of CD toxin A [54].

The hypothesis of antigenic presentation is also supported by the association between ReA-CDI and HLA B27 [54] and the high prevalence of HLA B27 patients in our review, compared to the general population, argues for a predisposition to ReA. Even patients without HLA B27 genotype were able to resolve ReA-CDI without any antibiotic treatment, providing corroborating evidence for non-septic arthritis. Unfortunately, we could not determine the HLA status of our patient.

Importantly, CD septic arthritis can only be excluded if there is no CD identified in the synovial fluid. In the literature, 28 negative articular liquid cultures were reported, on which only one CD-toxin PCR was performed [48]. In our opinion, the argument for a ReA-CDI diagnosis should require additional laboratory testing, such as specific culture for CD by toxin detection and 16S RNA analysis from articular liquid.

Even if the mechanisms underlying extra-colonic manifestations are unclear, some molecules like calprotectin (CP), interleukin (IL)-8 or IL-23 may play an important role in ReA-CDI [55]. CP is a calcium- and zinc-binding protein released from the cytosol after neutrophil activation [56]. CP has antibacterial, apoptosis-inducing, leukocyte-chemotactic properties and is a potential biomarker of inflammation [57], especially during inflammatory bowel disease's flare ups [59]. Fecal CP levels have also demonstrated strong correlation with neutrophil excretion in stool [60]. CP levels in the plasma and synovial fluid are also high during rheumatoid arthritis [61] and ReA [62]. CP has also been quantified in synovial tissue of rheumatoid arthritis patients, specifically in the lining adjacent to the cartilage-pannus junction, which is the primary site of cartilage destruction and bone erosion [61]. Of note, elevated levels of CP are also found in the feces of patients with CDI [58]. Further studies quantifying $C P$ in plasma and synovial fluid from ReA-CDI patients would be worthwhile in order to elucidate its potential role.

\section{CONCLUSION}


179 We reported a case of ReA-CDI and analyzed 49 other cases of ReA-CDI published in the literature.

180 Further studies are needed to determine the underlying pathophysiological mechanism behind ReA-

$181 \mathrm{CDI}$, while developing the role of specific ribotypes and CP.

182

185

186

187

188

189

190

191

192

193

194

195

196

197

198

199

200

201 
1. Cohen SH, Gerding DN, Johnson S, Kelly CP, Loo VG, McDonald LC, et al. Clinical practice guidelines for Clostridium difficile infection in adults: 2010 update by the society for healthcare epidemiology of America (SHEA) and the infectious diseases society of America (IDSA). Infect Control Hosp Epidemiol. 2010 May;31(5):431-55.

2. Lessa FC, Winston LG, McDonald LC, Emerging Infections Program C. difficile Surveillance Team. Burden of Clostridium difficile infection in the United States. N Engl J Med. 2015 Jun 11;372(24):2369-70.

3. CDC - Clostridium difficile Infection - HAI [Internet]. [cited 2015 Jul 7]. Available from: http://www.cdc.gov/HAl/organisms/cdiff/Cdiff_infect.html

4. Bauer MP, Notermans DW, van Benthem BHB, Brazier JS, Wilcox MH, Rupnik M, et al. Clostridium difficile infection in Europe: a hospital-based survey. Lancet Lond Engl. 2011 Jan 1;377(9759):63-73.

5. Bhargava A, Sen P, Swaminathan A, Ogbolu C, Chechko S, Stone F. Rapidly progressive necrotizing fasciitis and gangrene due to Clostridium difficile: case report. Clin Infect Dis Off Publ Infect Dis Soc Am. 2000 Jun;30(6):954-5.

6. Riley TV, Karthigasu KT. Chronic osteomyelitis due to Clostridium difficile. Br Med J Clin Res Ed. 1982 Apr 24;284(6324):1217-8.

7. Sofianou DC. Pancreatic abscess caused by Clostridium difficile. Eur J Clin Microbiol Infect Dis Off Publ Eur Soc Clin Microbiol. 1988 Aug;7(4):528-9.

8. Kumar N, Flanagan P, Wise C, Lord R. Splenic abscess caused by Clostridium difficile. Eur J Clin Microbiol Infect Dis Off Publ Eur Soc Clin Microbiol. 1997 Dec;16(12):938-9.

9. Simpson AJ, Das SS, Tabaqchali S. Nosocomial empyema caused by Clostridium difficile. J Clin Pathol. 1996 Feb;49(2):172-3.

10. Libby DB, Bearman G. Bacteremia due to Clostridium difficile--review of the literature. Int J Infect Dis IJID Off Publ Int Soc Infect Dis. 2009 Sep;13(5):e305-9.

11. Vaishnavi C. Clostridium difficile infection: clinical spectrum and approach to management. Indian J Gastroenterol Off J Indian Soc Gastroenterol. 2011 Dec;30(6):245-54. 
12. Mbonu CC, Davison DL, El-Jazzar KM, Simon GL. Clostridium difficile colitis associated with hemolytic-uremic syndrome. Am J Kidney Dis Off J Natl Kidney Found. 2003 May;41(5):E14.

13. Alvarado AS, Brodsky SV, Nadasdy T, Singh N. Hemolytic uremic syndrome associated with Clostridium difficile infection. Clin Nephrol. 2014 Apr;81(4):302-6.

14. Birnbaum J, Bartlett JG, Gelber AC. Clostridium difficile: an under-recognized cause of reactive arthritis? Clin Rheumatol. 2008 Feb 1;27(2):253-5.

15. Leffler DA, Lamont JT. Clostridium difficile Infection. N Engl J Med. 2015 Apr 16;372(16):153948.

16. Rothschild BM, Masi AT, June PL. Arthritis associated with ampicillin colitis. Arch Intern Med. 1977 Nov;137(11):1605-6.

17. Fairweather SD, Youngs D, George RH, Burdon DW, Keighley MR. Arthritis in pseudomembranous colitis associated with an antibody to Clostridium difficile toxin. J R Soc Med. $1980 \mathrm{Jul} ; 73(7): 524-5$.

18. Bolton RP, Wood GM, Losowsky MS. Acute arthritis associated with Clostridium difficile colitis. Br Med J Clin Res Ed. 1981 Oct 17;283(6298):1023-4.

19. Abbott WG, Caughey DE. Reactive arthritis due to Clostridium difficile. N Z Med J. 1982 Apr 28;95(706):287.

20. Puddey IB. Reiter's syndrome following antibiotic-associated colitis. Aust N Z J Med. 1982 Jun;12(3):292-3.

21. McCluskey J, Riley TV, Owen ET, Langlands DR. Reactive arthritis associated with Clostridium difficile. Aust N Z J Med. 1982 Oct;12(5):535-7.

22. Lofgren RP, Tadlock LM, Soltis RD. Acute oligoarthritis associated with Clostridium difficile pseudomembranous colitis. Arch Intern Med. 1984 Mar;144(3):617-9.

23. Caroli A, Cecchetto G, Sardeo G, Volpi A. [Acute reactive arthritis in pseudomembranous colitis]. Recenti Prog Med. 1986 Jun;77(6):316-8. 
24. Paty JG, Nichols RE. Arthritis and non-antibiotic-associated pseudomembranous colitis. Arthritis Rheum. 1987 Sep;30(9):1075-6.

25. Atkinson MH, McLeod BD. Reactive arthritis associated with Clostridium difficile enteritis. J Rheumatol. 1988 Mar;15(3):520-2.

26. Hannonen P, Hakola M, Möttönen T, Oka M. Reactive oligoarthritis associated with Clostridium difficile colitis. Scand J Rheumatol. 1989;18(1):57-60.

27. Mermel LA, Osborn TG. Clostridium difficile associated reactive arthritis in an HLA-B27 positive female: report and literature review. J Rheumatol. 1989 Jan;16(1):133-5.

28. Cope A, Anderson J, Wilkins E. Clostridium difficile toxin-induced reactive arthritis in a patient with chronic Reiter's syndrome. Eur J Clin Microbiol Infect Dis Off Publ Eur Soc Clin Microbiol. 1992 Jan;11(1):40-3.

29. Putterman C, Rubinow A. Reactive arthritis associated with Clostridium difficile pseudomembranous colitis. Semin Arthritis Rheum. 1993 Jun;22(6):420-6.

30. Sensini A, Marroni M, Bassotti G, Farinelli S, D’Alò F, Gentili AM, et al. Clostridium difficileassociated reactive arthritis in an HLA-B27 negative male. J Clin Gastroenterol. 1993 Jun;16(4):354-5.

31. Guillemin P, Gerster JC. [Reactive arthritis induced by Clostridium difficile enteritis]. Praxis. 2005 Mar 23;94(12):471-4.

32. Keating RM, Vyas AS. Reactive arthritis following Clostridium difficile colitis. West J Med. 1995 Jan;162(1):61-3.

33. Rochet N. Rheumatic manifestations of pseudomembranous colitis. Rev Rhum Engl Ed. 1995 Mar;62(3):223.

34. Wright TW, Linscheid RL, O'Duffy JD. Acute flexor tenosynovitis in association with Clostridium difficile infection: a case report. J Hand Surg. 1996 Mar;21(2):304-6.

35. Cron RQ, Gordon PV. Reactive arthritis to Clostridium difficile in a child. West J Med. 1997 Jun;166(6):419-21. 
36. Nikkari S, Yli-Kerttula U, Toivanen P. Reactive arthritis in a patient with simultaneous parvovirus B19 infection and Clostridium difficile diarrhoea. Br J Rheumatol. 1997 Jan;36(1):143-4.

37. Löffler HA, Pron B, Mouy R, Wulffraat NM, Prieur A-M. Clostridium difficile-associated reactive arthritis in two children. Jt Bone Spine Rev Rhum. 2004 Jan;71(1):60-2.

38. Veillard E, Guggenbuhl P, Bello S, Lamer F, Chalès G. Reactive oligoarthritis in a patient with Clostridium difficile pseudomembranous colitis. Review of the literature. Rev Rhum Engl Ed. 1998 Dec;65(12):795-8.

39. Koçar IH, Calişkaner Z, Pay S, Turan M. Clostridium difficile infection in patients with reactive arthritis of undetermined etiology. Scand J Rheumatol. 1998;27(5):357-62.

40. Söderlin MK, Alasaarela E, Hakala M. Reactive arthritis induced by Clostridium difficile enteritis as a complication of Helicobacter pylori eradication. Clin Rheumatol. 1999;18(4):337-8.

41. Vermeulen C, Lemaire V, Lioté F. [Joint manifestations related to Clostridium difficile]. Presse Médicale Paris Fr 1983. 2000 Mar 11;29(9):476-81.

42. Razavi B. Reactive arthritis after Helicobacter pylori eradication. Lancet. 2000 Feb 26;355(9205):720.

43. Jacobs A, Barnard K, Fishel R, Gradon JD. Extracolonic manifestations of Clostridium difficile infections. Presentation of 2 cases and review of the literature. Medicine (Baltimore). 2001 Mar;80(2):88-101.

44. Miner J, Gillan MM, Alex P, Centola M. Steroid-refractory ulcerative colitis treated with corticosteroids, metronidazole and vancomycin: a case report. BMC Gastroenterol. 2005;5:3.

45. Ducroix-Roubertou S, Genet C, Rogez JP, Weinbreck P, Denes E. [Reactive arthritis due to Clostridium difficile]. Médecine Mal Infect. 2005 Aug;35(7-8):419-21.

46. Durand MJ, Gutterman DD. Diversity in Mechanisms of Endothelium-Dependent Vasodilation in Health and Disease. Microcirc N Y N 1994. 2013 Apr;20(3):239-47.

47. Durand CL, Miller PF. Severe Clostridium difficile colitis and reactive arthritis in a ten-year-old child. Pediatr Infect Dis J. 2009 Aug;28(8):750-1. 
48. Ben Abdelghani K, Gerard-Dran D, Morel J, Combe B. [Clostridium difficile associated reactive arthritis]. Rev Médecine Interne Fondée Par Société Natl Francaise Médecine Interne. 2010 Mar;31(3):e13-5.

49. Case records of the Massachusetts General Hospital. Weekly clinicopathological exercises. Case 19-1998. A 70-year-old man with diarrhea, polyarthritis, and a history of Reiter's syndrome. N Engl J Med. 1998 Jun 18;338(25):1830-6.

50. Eckert C, Coignard B, Hebert M, Tarnaud C, Tessier C, Lemire A, et al. Clinical and microbiological features of Clostridium difficile infections in France: The ICD-RAISIN 2009 national survey. Médecine Mal Infect. 2013 Feb;43(2):67-74.

51. Davies KA, Longshaw CM, Davis GL, Bouza E, Barbut F, Barna Z, et al. Underdiagnosis of Clostridium difficile across Europe: the European, multicentre, prospective, biannual, pointprevalence study of Clostridium difficile infection in hospitalised patients with diarrhoea (EUCLID). Lancet Infect Dis. 2014 Dec;14(12):1208-19.

52. Granfors K, Jalkanen S, Lindberg AA, Mäki-Ikola O, von Essen R, Lahesmaa-Rantala R, et al. Salmonella lipopolysaccharide in synovial cells from patients with reactive arthritis. Lancet Lond Engl. 1990 Mar 24;335(8691):685-8.

53. Sánchez-Hurtado K, Poxton IR. Enhancement of the cytotoxic activity of Clostridium difficile toxin A by surface-associated antigens. J Med Microbiol. 2008 Jun;57(Pt 6):739-44.

54. Prati C, Bertolini E, Toussirot E, Wendling D. Reactive arthritis due to Clostridium difficile. Jt Bone Spine Rev Rhum. 2010 Mar;77(2):190-2.

55. Darkoh C, Turnwald BP, Koo HL, Garey KW, Jiang Z-D, Aitken SL, et al. Colonic Immunopathogenesis of Clostridium difficile Infections. Clin Vaccine Immunol CVI. 2014 Apr;21(4):509-17.

56. Vaos G, Kostakis ID, Zavras N, Chatzemichael A. The role of calprotectin in pediatric disease. BioMed Res Int. 2013;2013:542363.

57. Bressler B, Panaccione R, Fedorak RN, Seidman EG. Clinicians' guide to the use of fecal calprotectin to identify and monitor disease activity in inflammatory bowel disease. Can J Gastroenterol Hepatol. 2015 Jun 30; 
58. Konikoff MR, Denson LA. Role of fecal calprotectin as a biomarker of intestinal inflammation in inflammatory bowel disease. Inflamm Bowel Dis. 2006 Jun;12(6):524-34.

59. Røseth AG, Schmidt PN, Fagerhol MK. Correlation between faecal excretion of indium-111labelled granulocytes and calprotectin, a granulocyte marker protein, in patients with inflammatory bowel disease. Scand J Gastroenterol. 1999 Jan;34(1):50-4.

60. Hammer HB, Ødeg̊ard S, Fagerhol MK, Landewé R, van der Heijde D, Uhlig T, et al. Calprotectin (a major leucocyte protein) is strongly and independently correlated with joint inflammation and damage in rheumatoid arthritis. Ann Rheum Dis. 2007 Aug;66(8):1093-7.

61. Hammer HB, Kvien TK, Glennås A, Melby K. A longitudinal study of calprotectin as an inflammatory marker in patients with reactive arthritis. Clin Exp Rheumatol. 1995 Feb;13(1):5964.

62. Swale A, Miyajima F, Roberts P, Hall A, Little M, Beadsworth MBJ, et al. Calprotectin and lactoferrin faecal levels in patients with Clostridium difficile infection (CDI): a prospective cohort study. PloS One. 2014;9(8):e106118. 


\begin{tabular}{|c|c|c|c|c|c|c|c|c|c|c|}
\hline $\begin{array}{c}\text { AUTHOR } \\
\text { YEAR OF PUBLICATION }\end{array}$ & SEX & $\begin{array}{c}\text { AGE } \\
\text { (years) }\end{array}$ & $\begin{array}{l}\text { HLA } \\
\text { B27 }\end{array}$ & $\begin{array}{l}\text { REASON FOR } \\
\text { PRESCRIBING ATB } \\
\text { BEFORE CDI }\end{array}$ & $\begin{array}{l}\text { ATB BEFORE } \\
\text { CDI }\end{array}$ & $\begin{array}{l}\text { ATB USED } \\
\text { TO TREAT } \\
\text { CDI }\end{array}$ & $\begin{array}{c}\text { TUI } \\
\text { (days) }\end{array}$ & LOCATION OF ARTHRITIS & OUTCOME & $\begin{array}{l}\text { SYMPTOM DURATION } \\
\text { (days) }\end{array}$ \\
\hline Rollins et al. 1976 & M & 55 & NA & ENT infection & $\beta$-lact & NA & 35 & Elbow, Wrist, Knee, Foot & NA, Resolution & 5 \\
\hline Rothschild et al. 1977 & $\mathrm{~F}$ & 23 & NA & Genital infection & $\beta$-lact & NA & 8 & Knee & NA, Resolution & 5 \\
\hline Bolton et al. 1981 & $\mathrm{~F}$ & 45 & - & Skin infection & Linc & IMDZ & 21 & Knee, Ankle & NSAID, Resolution & 43 \\
\hline Abbott et al. 1982 & $\mathrm{~F}$ & 27 & - & NA & $\beta$-lact & NA & 8 & Elbow, Wrist, Knee & NA, Resolution & 42 \\
\hline Puddey et al. 1982 & M & 48 & + & Skin infection & $\beta$-lact & NA & 16 & Knee & NA, Resolution & 56 \\
\hline McCluskey 1982 & $\mathrm{~F}$ & 37 & + & Skin infection & Linc & NA & 14 & Wrist, Knee, Ankle & NA, Resolution & 29 \\
\hline Lofgren et al. 1984 & M & 61 & + & Prophylaxis & $\beta$-lact & GLP & 11 & Hip, Knee & 0 , Resolution & 14 \\
\hline Paty et al. 1987 & $\mathrm{~F}$ & 28 & - & 0 & 0 & NA & 28 & Wrist, Hand, Knee, Ankle & NA, Resolution & 21 \\
\hline Atkinson et al. 1988 & M & 22 & - & Prophylaxis & $\beta$-lact & NA & 0 & Shoulder, Wrist, Ankle & NA, Resolution & 200 \\
\hline Atkinson et al. 1988 & M & 44 & + & Skin infection & $\beta$-lact & NA & 16 & Knee, Ankle & NA, Resolution & 22 \\
\hline Hannonen et al. 1989 & $\mathrm{~F}$ & 23 & + & Other & Linc & NA & 10 & Wrist, Hand, Knee & NA, Resolution & 60 \\
\hline Mermel et al. 1989 & $\mathrm{~F}$ & 29 & + & Genital infection & $\beta$-lact & NA & 11 & Hand, Knee, Ankle, Other & NA, Persistence & 730 \\
\hline Hannonen et al. 1989 & $M$ & 45 & + & ENT infection & $\beta$-lact & NA & 8 & Wrist & NA, Resolution & 210 \\
\hline Hannonen et al. 1989 & $\mathrm{~F}$ & 36 & - & ENT infection & Linc & NA & 12 & Wrist, Ankle & NA, Resolution & 30 \\
\hline Limonta et al. 1989 & $\mathrm{~F}$ & 24 & NA & ENT infection & IMDZ & NA & 3 & Elbow, Hand, Ankle & NA, Resolution & 21 \\
\hline Limonta et al. 1989 & $\mathrm{~F}$ & 25 & + & Other & 0 & NA & 8 & Elbow, Hand, Ankle & NA, Resolution & 28 \\
\hline Cope et al. 1992 & M & 48 & + & Skin infection & $\beta$-lact & NA & 14 & Wrist, Hand, Knee, Ankle & NA, Persistence & 801 \\
\hline Guillemin et al. 1994 & $\mathrm{~F}$ & 999 & + & NA & NA & NA & NA & Ankle & NA & NA \\
\hline Keating et al. 1995 & M & 26 & + & ENT infection & $\beta$-lact & IMDZ & 3 & Wrist, Hand, Ankle & LCS, Resolution & 43 \\
\hline Rochet et al. 1995 & $\mathrm{~F}$ & 68 & + & NA & $\beta$-lact & NA & 0 & Elbow, Knee, Ankle, Foot & NA, Resolution & 8 \\
\hline Wright et al. 1996 & $\mathrm{~F}$ & 36 & + & ENT infection & $\beta$-lact & GLP & 5 & Shoulder, Wrist, Knee & 0 , Resolution & 42 \\
\hline Cron et al. 1997 & M & 3 & NA & ENT infection & $\beta$-lact & GLP & 20 & Knee & NSAID, Resolution & 90 \\
\hline Nikkari et al. 1997 & $\mathrm{~F}$ & 34 & + & Other infection & $\beta$-lact & IMDZ & 7 & Wrist, Ankle & NA, Persistence & 366 \\
\hline Löffler et al. 1998 & $\mathrm{~F}$ & $\begin{array}{l}24 \\
6\end{array}$ & - & 0 & 0 & GLP & NA & Elbow, Shoulder, Wrist, Knee & NSAID, Resolution & 7 \\
\hline Robert et al. 1998 & M & 70 & NA & ENT infection & $\beta$-lact & NA & 2 & Hand, Ankle, Foot & NSAID, Resolution & 120 \\
\hline Veillard et al. 1998 & M & 57 & + & ENT infection & $\beta$-lact & NA & 19 & Elbow, Knee, Other & NSAID + LCS, Resolution & 15 \\
\hline Kocar et al. 1998 & M & 20 & - & NA & $\beta$-lact & GLP & 10 & NA & NA, Resolution & 27 \\
\hline Kocar et al. 1998 & M & 20 & - & NA & $\beta$-lact & GLP & 30 & NA & NA & NA \\
\hline Kocar et al. 1998 & M & 21 & - & NA & $\beta$-lact & GLP & 20 & NA & NA & NA \\
\hline Kocar et al. 1998 & M & 23 & + & NA & $\beta$-lact & GLP & 10 & NA & NA, Resolution & 21 \\
\hline Kocar et al. 1998 & $\mathrm{~F}$ & 25 & + & NA & $\beta$-lact & GLP & 7 & NA & NA, Resolution & 25 \\
\hline Kocar et al. 1998 & $\mathrm{~F}$ & 25 & + & NA & 0 & GLP & NA & NA & NA & NA \\
\hline Soderlin et al. 1999 & $\mathrm{~F}$ & 65 & + & Digestive infection & $\beta$-lact & NA & 4 & Ankle & NA, Resolution & 330 \\
\hline Vermeulen et al. 2000 & $\mathrm{~F}$ & 22 & + & ENT infection & $\beta$-lact & NA & 7 & Shoulder, Hand, Knee & NA & NA \\
\hline Vermeulen et al. 2000 & $M$ & 67 & + & Respiratory infection & Linc & NA & 28 & Wrist, Ankle & NA, Resolution & 140 \\
\hline Razavi et al. 2000 & $M$ & 47 & + & Digestive infection & $\beta$-lact & IMDZ & 14 & Hip, Ankle, Other & NSAID, Resolution & 121 \\
\hline Jacobs A. et al. 2001 & $\mathrm{~F}$ & 36 & + & Other infection & $\beta$-lact & IMDZ & 7 & Knee & 0 , Resolution & 14 \\
\hline Delegue P et al. 2001 & $\mathrm{~F}$ & 28 & + & Urinary infection & $\beta$-lact & IMDZ & 5 & Hand, Knee, Ankle & 0, Resolution & 90 \\
\hline Durand et al. 2008 & $\mathrm{~F}$ & 10 & NA & ENT infection & $\beta$-lact & IMDZ & 30 & Hip & Surgery, Resolution & 20 \\
\hline Prati et al. 2008 & $\mathrm{~F}$ & 64 & + & Respiratory infection & $\beta$-lact & IMDZ & 17 & Elbow, Ankle & 0 , Resolution & 10 \\
\hline Birnbaum et al. 2008 & M & 72 & + & Respiratory infection & Linc & IMDZ & 55 & Shoulder, Knee, Ankle & NSAID + LCS, Resolution & 110 \\
\hline Ben Abdelghani et al. 2009 & $\mathrm{~F}$ & 43 & - & 0 & 0 & IMDZ & NA & Shoulder, Wrist, Ankle & SCS, Resolution & 110 \\
\hline
\end{tabular}

Table 1: Literature review of all cases of reactive arthritis associated with Clostridium difficile ( $N=49$ ).

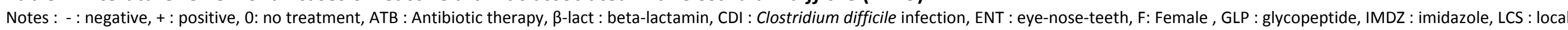

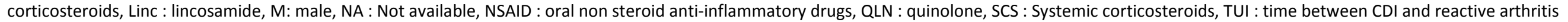




\section{HIGHLIGHTS}

- Clostridium difficile associated reactive arthritis are uncommon.

- It is more likely observed in younger patients with HLA B27-positive genotype.

- Outcome was favorable in $90 \%$ of patients. 